\title{
Bentley et al.
}

\section{Supplemental Information}

Deglacial history of the West Antarctic Ice Sheet in the Weddell Sea embayment: constraints on past ice volume change.

Bentley, M.J.*, Fogwill, C.J., Le Brocq, A.M., Hubbard, A.L., Sugden, D.E., Dunai, T.J., Freeman. S.

*E-mail: m.j.bentley@durham.ac.uk

This pdf contains

SupplementalText

Figures DR1-DR5

Table DR1

References 


\section{Cosmogenic isotope analysis}

\section{Introduction}

As a result of secondary cosmic ray bombardment, ${ }^{10} \mathrm{Be}$ and other in situ cosmogenic nuclides are produced in the uppermost decimeters of the Earth's surface within certain target minerals, in concentrations which can be measured using Accelerator Mass Spectrometry (AMS). The measured isotopic ratio can be converted into a concentration of the cosmogenic isotope and therefore used to calculate an exposure age or erosion rate, providing the production rate of the isotope in question is known and the geomorphic history of the sample is well understood (Gosse and Phillips, 2001).

\section{Field sampling protocols}

We sampled a range of glacially transported erratics for cosmogenic isotope analysis in order to establish a detailed record of ice sheet surface profile change through time in the Heritage Range of the Ellsworth Mountains (Fig DR1). As quartz is the primary target mineral for production of cosmogenic ${ }^{10} \mathrm{Be}$, we preferentially sampled quartz-rich erratics, including quartzites, sandstones, granitic lithogies and some metasediments from ice free bedrock and till-covered surfaces in the eastern Heritage Range of The Ellsworth Mountains. Samples varied from small cobbles ( $\sim 15 \mathrm{~cm}$ long axis) through to large $\left(\sim 1 \mathrm{~m}^{2}\right)$ boulders. For larger erratics, we preferentially sampled the upper surface to ensure maximum possible cosmogenic isotope production, and minimal snow cover throughout the exposure period. The samples collected reflect a full altitudinal profile of the mountains, in order to constrain the long term thinning trajectory of the ice sheet surface since the Last Glacial Maximum (Mackintosh et al., 2007; Stone et al., 2003). Sample locations and ages are shown in Figure DR2, and plotted against height above present-day ice in Fig DR3 (all samples) and Fig 2 (samples $<50 \mathrm{ka}$ ).

\section{Laboratory Procedures}

Beryllium was selectively extracted from the quartz component of the whole rock sample, following the standard procedures at the University of Edinburgh Cosmogenic Isotope 
Laboratory (Ivy-Ochs, 1996; Kohl and Nishiizumi, 1992). A reference $0.25 \mathrm{mg}$ 'spike' of commercially available non-cosmogenic ${ }^{9} \mathrm{Be}$ carrier solution (Scharlab Be solution; concentration $984 \pm 2 \mathrm{ppm}$ ) was added to each sample and the corresponding blank. The ${ }^{10} \mathrm{Be} /{ }^{9} \mathrm{Be}$ ratios were measured at the Scottish Universities Environmental Research Centre (SUERC) AMS laboratory (Freeman et al., 2004). Measured ratios were normalised to NIST SRM4325 with a calibrated ${ }^{10} \mathrm{Be} /{ }^{9} \mathrm{Be}$ ratio of $3.06 \times 10^{-11}$. This ratio agrees to within $<0.5 \%$ with measurements from standard materials provided from $\mathrm{K}$. Nishiizumi (Nishiizumi, 2002). The nominal ratios used for primary and secondary standards disagree with the re-calibration reported by (Nishiizumi et al., 2007), although the production rates used are consistent with the ratios used in this work. As a result, the ${ }^{10} \mathrm{Be}$ concentrations reported here would be affected by implementing revised ${ }^{10} \mathrm{Be} /{ }^{9} \mathrm{Be}$ ratios, but the exposure ages would not. The measured sample concentrations were corrected by full chemistry procedural blanks, which had ${ }^{10} \mathrm{Be} /{ }^{9} \mathrm{Be}$ ratios ranging from $5.96 \times 10^{-15}$ to $1.67 \times 10^{-14}$. This ratio was subtracted from the $\mathrm{Be}$ isotope ratios of the samples, with blank-corrected ${ }^{10} \mathrm{Be} /{ }^{9} \mathrm{Be}$ ratios of the samples ranging from $9.45 \times 10^{-15}$ to $9.05 \times 10^{-12}$. Final analytical error in concentration (at. $\mathrm{g}^{-1}$ ) is derived from a sum in quadrature of the standard mean error of the measured AMS ratio and 2\% in the Be 'spike' assay (measured by ICP-AES).

Apparent exposure ages (Table DR1) were generated using a ${ }^{10} \mathrm{Be}$ production rate scaled to sea level high latitude (SLHL) in Antarctica using the CRONUS-Earth Online calculator of (Balco et al., 2008). We used the following version: Wrapper script 2.2; Main calculator 2.1; Constants 2.2; Muons 1.1. The exposure ages outlined in Table DR1 are based on the constant production rate model and using the Antarctic pressure scaling model (Lal, 1991; Stone, 2000). This was chosen in favour of other time varying production models as corrections due to variations in the palaeogeomagnetic dipole intensity are not required for high latitude sites. Further, at high latitude and the altitude range of our sampling sites (700-1400 $\mathrm{m}$ ), the pressure dependent altitude scaling of all currently used scaling factors differ marginally $(<3 \%)$ from each other. Therefore our calculated ages are not significantly affected by the choice of the scaling model used. Sample thickness (selfshielding) corrections were calculated using an attenuation coefficient of $160 \mathrm{~g} \mathrm{~cm}^{-2}$ and a 
rock density of $2.65 \mathrm{~g} \mathrm{~cm}^{-3}$. We report full external uncertainties in single-nuclide exposure ages, representing full propagation of the production rate uncertainty together with the AMS measurement errors defined above. This allows direct inter-comparison with data from different geographical locations and different chronological techniques. The reduction of production rates by intermittent snow cover is unlikely since the samples were collected from the tops of large boulders and/or exposed ridge crests, where storms would rapidly blow snow off the surfaces. Hence we do not correct for potential snow cover. 
Table DR1. Cosmogenic sample details, AMS measurement data and calculated exposure ages. Notes: ${ }^{1}$ sample latitude and longitude, ${ }^{2}$ sample elevation measured by GPS $( \pm 10 \mathrm{~m}),{ }^{3}$ elevation normalised to elevation above present-day ice sheet surface, in order to allow intercomparison of sites, ${ }^{4}$ depth dependent shielding correction (Gosse and Phillips, 2001), ${ }^{5}$ Calculated using the relationship sin ${ }^{2.3} \theta$, integrated around the horizon and where $\theta$ is angle of the horizon above the horizontal (Ivy-Ochs, 1996), ${ }^{6}$ exposure ages and errors calculated using The CRONUS-Earth On-line calculator in thousands of years (ka) (Balco et al., 2008). 


\begin{tabular}{|c|c|c|c|c|c|c|c|c|c|c|c|c|}
\hline Sample name & $\begin{array}{l}\text { Lat. } \\
\left({ }^{\circ} \mathrm{S}\right)^{1}\end{array}$ & $\begin{array}{l}\text { Long. } \\
\left({ }^{\circ} \mathrm{W}\right)^{1}\end{array}$ & $\begin{array}{l}\text { Elevation } \\
(\mathrm{m})^{2}\end{array}$ & $\begin{array}{l}\text { Normalised } \\
\text { elevation } \\
(\mathrm{m})^{3}\end{array}$ & ${ }^{10} \mathrm{Be}$ (at/g) & $\begin{array}{c} \pm^{10} \text { Be error } \\
\text { (at/g) }\end{array}$ & $\begin{array}{l}\text { Thickness } \\
\text { Correction }^{4}\end{array}$ & $\begin{array}{l}\text { Shielding } \\
\text { Correction }^{5}\end{array}$ & $\begin{array}{c}\text { Muon } \\
\text { production } \\
\text { rate } \\
(a t / g / y r)^{6}\end{array}$ & $\begin{array}{c}\text { Spallation } \\
\text { prod rate } \\
\text { (at/g/yr) }^{6}\end{array}$ & $\begin{array}{c}{ }^{10} \mathrm{Be} \\
\text { Exposure } \\
\text { Age }(\mathrm{ka})^{6}\end{array}$ & $\begin{array}{c} \pm{ }^{10} \mathrm{Be} \\
\text { externa } \\
\text { error } \\
(\mathrm{ka})^{6}\end{array}$ \\
\hline \multicolumn{13}{|l|}{ Patriot Hills (E) } \\
\hline CF-01-08 & 80.3263 & 81.3345 & 760 & 0 & $1.67 \mathrm{E}+05$ & $8.51 \mathrm{E}+03$ & 0.96 & 0.98 & 0.25 & 11.14 & 13.4 & 1.4 \\
\hline CF-02-08 & 80.3265 & 81.3312 & 760 & 0 & $9.41 \mathrm{E}+03$ & $1.33 \mathrm{E}+03$ & 0.96 & 0.99 & 0.25 & 11.25 & 0.7 & 0.1 \\
\hline CF-03-08 & 80.3268 & 81.3269 & 762 & 2 & $6.19 \mathrm{E}+03$ & $4.13 \mathrm{E}+02$ & 0.96 & 0.98 & 0.25 & 11.16 & 0.5 & 0.1 \\
\hline CF-08-08 & 80.3313 & 81.3867 & 1014 & 254 & $5.65 E+06$ & $5.47 \mathrm{E}+04$ & 0.96 & 0.98 & 0.28 & 13.95 & 400.8 & 38.9 \\
\hline CF-09-08 & 80.3314 & 81.3857 & 1004 & 244 & $5.83 \mathrm{E}+06$ & $7.19 \mathrm{E}+04$ & 0.96 & 0.99 & 0.28 & 13.97 & 414.7 & 40.5 \\
\hline CF-13-08 & 80.3306 & 81.3832 & 989 & 229 & $1.06 \mathrm{E}+06$ & $1.75 \mathrm{E}+04$ & 0.96 & 0.97 & 0.27 & 13.51 & 71.6 & 6.4 \\
\hline CF-14-08 & 80.3306 & 81.3652 & 935 & 175 & $4.76 \mathrm{E}+05$ & $1.29 \mathrm{E}+04$ & 0.96 & 0.97 & 0.27 & 12.88 & 33.3 & 3.1 \\
\hline CF-17-08 & 80.3305 & 81.3300 & 826 & 66 & $5.96 \mathrm{E}+05$ & $1.60 \mathrm{E}+04$ & 0.96 & 0.97 & 0.26 & 11.70 & 46.0 & 4.2 \\
\hline CF-19-08 & 80.3303 & 81.3300 & 816 & 56 & $2.75 \mathrm{E}+05$ & $6.30 \mathrm{E}+03$ & 0.96 & 0.97 & 0.26 & 11.59 & 21.3 & 1.9 \\
\hline CF-21-08 & 80.3295 & 81.3267 & 774 & 14 & $5.02 \mathrm{E}+04$ & $1.29 \mathrm{E}+03$ & 0.96 & 0.99 & 0.25 & 11.39 & 3.9 & 0.4 \\
\hline CF-24-08 & 80.3292 & 81.3254 & 761 & 1 & $3.76 \mathrm{E}+04$ & $5.00 \mathrm{E}+02$ & 0.96 & 0.97 & 0.25 & 11.03 & 3.0 & 0.3 \\
\hline CF-25-08 & 80.3236 & 81.4352 & 940 & 180 & $6.45 \mathrm{E}+05$ & $1.64 \mathrm{E}+04$ & 0.96 & 0.97 & 0.27 & 12.94 & 45.1 & 4.1 \\
\hline CF-28-08 & 80.3230 & 81.4347 & 879 & 119 & $7.12 \mathrm{E}+05$ & $1.85 \mathrm{E}+04$ & 0.96 & 0.97 & 0.26 & 12.26 & 52.6 & 4.8 \\
\hline CF-29-08 & 80.3224 & 81.4341 & 879 & 119 & 4.08E+05 & $1.09 \mathrm{E}+04$ & 0.96 & 0.97 & 0.26 & 12.26 & 30.0 & 2.7 \\
\hline CF-31-08 & 80.3219 & 81.4343 & 863 & 103 & $1.85 \mathrm{E}+05$ & $4.25 \mathrm{E}+03$ & 0.96 & 0.97 & 0.26 & 12.09 & 13.7 & 1.2 \\
\hline PAT-04-CJF & 80.3309 & 81.3848 & 933 & 173 & $4.25 \mathrm{E}+05$ & $1.14 \mathrm{E}+04$ & 0.96 & 0.97 & 0.27 & 12.86 & 29.8 & 2.7 \\
\hline PAT-08-CJF & 80.3300 & 81.3819 & 1004 & 244 & $5.54 \mathrm{E}+06$ & $8.78 \mathrm{E}+04$ & 0.96 & 0.97 & 0.28 & 13.68 & 400.2 & 39.2 \\
\hline PAT-10-CJF & 80.3295 & 81.3791 & 1002 & 242 & $6.09 \mathrm{E}+06$ & $1.08 \mathrm{E}+05$ & 0.96 & 0.97 & 0.28 & 13.66 & 446.0 & 44.4 \\
\hline PAT-13-CJF & 80.3279 & 81.3389 & 978 & 218 & $5.25 \mathrm{E}+06$ & $9.61 \mathrm{E}+04$ & 0.96 & 0.97 & 0.27 & 13.38 & 387.1 & 38.0 \\
\hline PAT-14-CJF & 80.3280 & 81.3374 & 968 & 208 & $1.12 \mathrm{E}+06$ & $2.14 \mathrm{E}+04$ & 0.96 & 0.97 & 0.27 & 13.26 & 77.2 & 7.0 \\
\hline PAT-15-CJF & 80.3275 & 81.3435 & 965 & 205 & $1.08 \mathrm{E}+06$ & $1.46 \mathrm{E}+04$ & 0.96 & 0.97 & 0.27 & 13.23 & 74.4 & 6.7 \\
\hline PAT-16-CJF & 80.3285 & 81.3538 & 960 & 200 & $7.40 \mathrm{E}+05$ & $2.05 E+04$ & 0.96 & 0.97 & 0.27 & 13.17 & 50.9 & 4.7 \\
\hline PAT-18-CJF & 80.3283 & 81.3541 & 774 & 14 & $4.10 \mathrm{E}+05$ & $9.60 \mathrm{E}+03$ & 0.96 & 0.97 & 0.25 & 11.16 & 33.0 & 3.0 \\
\hline РAT-20-CJF & 80.3283 & 81.3541 & 772 & 12 & $9.83 E+05$ & 1.06E+04 & 0.96 & 0.97 & 0.25 & 11.14 & 80.4 & 7.2 \\
\hline PAT-21-CJF & 80.3282 & 81.5026 & 769 & 9 & $4.10 \mathrm{E}+05$ & $6.99 \mathrm{E}+03$ & 0.96 & 0.97 & 0.25 & 11.11 & 33.2 & 3.0 \\
\hline PAT-24-CJF & 80.3251 & 81.5332 & 777 & 17 & $3.89 \mathrm{E}+05$ & $8.01 \mathrm{E}+03$ & 0.96 & 0.97 & 0.25 & 11.19 & 31.3 & 2.8 \\
\hline PAT-25-CJF & 80.3245 & 81.5359 & 775 & 15 & $4.57 \mathrm{E}+05$ & $7.20 \mathrm{E}+03$ & 0.96 & 0.97 & 0.25 & 11.17 & 36.8 & 3.3 \\
\hline PAT-26-CJF & 80.3235 & 81.5416 & 775 & 15 & $5.61 \mathrm{E}+05$ & $1.20 \mathrm{E}+04$ & 0.96 & 0.97 & 0.25 & 11.40 & 44.4 & 4.0 \\
\hline \multicolumn{13}{|l|}{ Patriot Hills (W) } \\
\hline PAT-01-MJB & 80.3301 & 81.3654 & 1092 & 192 & $1.38 \mathrm{E}+05$ & $3.91 \mathrm{E}+03$ & 0.96 & 0.99 & 0.28 & 15.06 & 8.2 & 0.8 \\
\hline PAT-03-MJB & 80.3307 & 81.3868 & 1009 & 109 & $8.75 E+04$ & 2.67E+04 & 0.96 & 0.97 & 0.28 & 13.74 & 5.7 & 1.8 \\
\hline PAT-04-MJB & 80.3303 & 81.3813 & 998 & 98 & $1.40 \mathrm{E}+05$ & $1.01 \mathrm{E}+04$ & 0.96 & 0.99 & 0.28 & 13.89 & 9.0 & 1.0 \\
\hline PAT-05-MJB & 80.3300 & 81.3819 & 954 & 54 & $9.68 \mathrm{E}+04$ & $1.12 \mathrm{E}+04$ & 0.96 & 0.97 & 0.27 & 13.10 & 6.6 & 1.0 \\
\hline
\end{tabular}




\begin{tabular}{|c|c|c|c|c|c|c|c|c|c|c|c|c|}
\hline Sample name & $\begin{array}{l}\text { Lat. } \\
\left({ }^{\circ} \mathrm{S}\right)^{1}\end{array}$ & $\begin{array}{l}\text { Long. } \\
\left({ }^{\circ} W\right)^{1}\end{array}$ & $\begin{array}{l}\text { Elevation } \\
(\mathrm{m})^{2}\end{array}$ & $\begin{array}{c}\text { Normalised } \\
\text { elevation } \\
(\mathrm{m})^{3}\end{array}$ & ${ }^{10} \mathrm{Be}(\mathrm{at} / \mathrm{g})$ & $\begin{array}{c} \pm{ }^{10} \mathrm{Be} \text { error } \\
\text { (at/g) }\end{array}$ & $\begin{array}{l}\text { Thickness } \\
\text { Correction }^{4}\end{array}$ & $\begin{array}{l}\text { Shielding } \\
\text { Correction }^{5}\end{array}$ & $\begin{array}{c}\text { Muon } \\
\text { production } \\
\text { rate } \\
{\text { (at } / g / y r)^{6}}^{6}\end{array}$ & $\begin{array}{l}\text { Spallation } \\
\text { prod rate } \\
{\text { (at } / g / y r)^{6}}^{6}\end{array}$ & $\begin{array}{c}{ }^{10} \mathrm{Be} \\
\text { Exposure } \\
\text { Age }(\mathrm{ka})^{6}\end{array}$ & $\begin{array}{c} \pm{ }^{{ }^{10} \mathrm{Be}} \\
\text { external } \\
\text { error } \\
(\mathrm{ka})^{6}\end{array}$ \\
\hline \multicolumn{13}{|l|}{ Marble Hills } \\
\hline CF-222-08 & 80.2591 & 82.1650 & 1126 & 306 & $6.41 \mathrm{E}+05$ & $7.86 \mathrm{E}+03$ & 0.96 & 0.98 & 0.33 & 18.06 & 35.1 & 3.1 \\
\hline CF-223-08 & 80.2591 & 82.1650 & 1126 & 306 & $7.30 \mathrm{E}+05$ & $1.92 \mathrm{E}+04$ & 0.96 & 0.99 & 0.33 & 18.26 & 39.6 & 3.6 \\
\hline CF-224-08 & 80.2580 & 82.1584 & 1126 & 306 & $9.89 \mathrm{E}+05$ & $2.76 \mathrm{E}+04$ & 0.96 & 0.99 & 0.32 & 17.13 & 57.4 & 5.3 \\
\hline CF-225-08 & 80.2580 & 82.1584 & 1032 & 212 & $8.79 \mathrm{E}+05$ & $2.41 \mathrm{E}+04$ & 0.96 & 0.99 & 0.32 & 17.13 & 51.0 & 4.7 \\
\hline CF-227-08 & 80.2571 & 82.1487 & 1032 & 212 & $5.52 \mathrm{E}+05$ & $1.53 \mathrm{E}+04$ & 0.96 & 0.99 & 0.31 & 15.81 & 34.5 & 3.2 \\
\hline CF-228-08 & 80.2574 & 82.1328 & 986 & 166 & $8.36 \mathrm{E}+04$ & $1.80 \mathrm{E}+03$ & 0.96 & 0.99 & 0.30 & 15.19 & 5.4 & 0.5 \\
\hline CF-229-08 & 80.2574 & 82.1328 & 986 & 166 & $7.18 \mathrm{E}+04$ & $1.72 \mathrm{E}+03$ & 0.96 & 0.99 & 0.30 & 15.19 & 4.6 & 0.4 \\
\hline CF-230-08 & 80.2574 & 82.1261 & 950 & 130 & $1.32 \mathrm{E}+05$ & $3.16 \mathrm{E}+03$ & 0.96 & 0.99 & 0.30 & 14.72 & 8.8 & 0.8 \\
\hline CF-231-08 & 80.2574 & 82.1261 & 950 & 130 & $4.66 \mathrm{E}+03$ & 3.06E+02 & 0.96 & 0.99 & 0.30 & 14.65 & 0.3 & 0.0 \\
\hline MAR-02-CJF & 80.2627 & 82.1868 & 1385 & 565 & $7.51 \mathrm{E}+06$ & $1.82 \mathrm{E}+05$ & 0.96 & 0.99 & 0.35 & 21.23 & 379.5 & 37.3 \\
\hline MAR-04-MJB & 80.2614 & 82.1700 & 1246 & 426 & $3.73 \mathrm{E}+06$ & $9.24 \mathrm{E}+04$ & 0.96 & 0.99 & 0.33 & 18.94 & 202.7 & 19.2 \\
\hline MAR-05-MJB & 80.2615 & 82.1692 & 1192 & 372 & $1.22 \mathrm{E}+05$ & $3.09 \mathrm{E}+03$ & 0.96 & 0.97 & 0.33 & 17.74 & 6.8 & 0.6 \\
\hline MAR-06-MJB & 80.2615 & 82.1696 & 1166 & 346 & $1.31 \mathrm{E}+05$ & $5.91 \mathrm{E}+03$ & 0.96 & 0.97 & 0.32 & 17.36 & 7.4 & 0.7 \\
\hline MAR-07-CJF & 80.2620 & 82.1611 & 1302 & 482 & $5.55 E+05$ & $1.26 \mathrm{E}+04$ & 0.96 & 0.99 & 0.34 & 19.81 & 27.7 & 2.5 \\
\hline MAR-08-CJF & 80.2620 & 82.1611 & 1302 & 482 & $6.66 \mathrm{E}+05$ & $5.77 \mathrm{E}+04$ & 0.96 & 0.99 & 0.34 & 19.84 & 33.3 & 4.1 \\
\hline MAR-08-MJB & 80.2613 & 82.0857 & 1002 & 182 & $9.60 \mathrm{E}+04$ & $9.47 \mathrm{E}+02$ & 0.96 & 0.97 & 0.30 & 15.09 & 6.2 & 0.5 \\
\hline MAR-09-CJF & 80.2631 & 82.0985 & 1305 & 485 & $3.05 E+05$ & $2.27 \mathrm{E}+03$ & 0.96 & 0.99 & 0.34 & 19.89 & 15.1 & 1.3 \\
\hline MAR-10-CJF & 80.2364 & 82.2150 & 1280 & 460 & $4.80 \mathrm{E}+06$ & $1.08 \mathrm{E}+05$ & 0.96 & 0.99 & 0.33 & 19.49 & 256.8 & 24.4 \\
\hline MAR-10-MJB & 80.2362 & 82.2016 & 974 & 154 & $1.75 E+05$ & $3.28 \mathrm{E}+03$ & 0.96 & 0.99 & 0.30 & 15.03 & 11.4 & 1.0 \\
\hline MAR-11-CJF & 80.2350 & 82.1827 & 1280 & 460 & $3.05 E+05$ & $9.96 \mathrm{E}+03$ & 0.96 & 0.99 & 0.33 & 19.49 & 15.4 & 1.4 \\
\hline MAR-11-MJB & 80.2374 & 82.1703 & 810 & 0 & $2.82 \mathrm{E}+04$ & $6.60 \mathrm{E}+02$ & 0.96 & 0.99 & 0.28 & 13.00 & 2.1 & 0.2 \\
\hline MAR-12-MJB & 80.2628 & 82.1382 & 807 & 0 & $3.60 \mathrm{E}+04$ & $2.18 \mathrm{E}+03$ & 0.96 & 0.97 & 0.28 & 12.70 & 2.8 & 0.3 \\
\hline MAR-13-CJF & 80.2629 & 82.1236 & 1112 & 292 & $3.49 \mathrm{E}+06$ & $7.85 \mathrm{E}+04$ & 0.96 & 0.99 & 0.32 & 16.93 & 212.5 & 20.0 \\
\hline MAR-16-CJF & 80.2631 & 82.0985 & 1117 & 297 & 7.91E+05 & $1.89 \mathrm{E}+04$ & 0.96 & 0.99 & 0.32 & 17.00 & 46.2 & 4.2 \\
\hline MAR-17-MJB & 80.2643 & 82.0784 & 959 & 139 & $1.20 \mathrm{E}+06$ & $2.71 \mathrm{E}+04$ & 0.96 & 0.99 & 0.30 & 14.84 & 80.8 & 7.4 \\
\hline MAR-18-MJB & 80.2656 & 82.0760 & 943 & 123 & 4.15E+05 & $8.75 E+03$ & 0.96 & 0.99 & 0.30 & 14.63 & 28.0 & 2.5 \\
\hline MAR-19-CJF & 80.2634 & 82.0343 & 1109 & 289 & $5.59 \mathrm{E}+05$ & $1.04 \mathrm{E}+04$ & 0.96 & 0.99 & 0.32 & 16.80 & 32.9 & 2.9 \\
\hline MAR-19-MJB & 80.2633 & 82.0350 & 936 & 116 & $4.21 \mathrm{E}+05$ & $1.30 \mathrm{E}+04$ & 0.96 & 0.99 & 0.30 & 14.54 & 28.6 & 2.6 \\
\hline MAR-20-MJB & 80.2353 & 82.1868 & 900 & 80 & $4.05 \mathrm{E}+05$ & $7.65 E+03$ & 0.96 & 0.99 & 0.29 & 14.09 & 28.4 & 2.5 \\
\hline MAR-21-CJF & 80.2350 & 82.1808 & 1040 & 220 & $3.55 \mathrm{E}+06$ & $8.49 \mathrm{E}+04$ & 0.96 & 0.99 & 0.31 & 15.92 & 230.7 & 21.9 \\
\hline MAR-24-CJF & 80.2357 & 82.1778 & 953 & 133 & $5.12 \mathrm{E}+05$ & $1.24 \mathrm{E}+04$ & 0.96 & 0.99 & 0.30 & 14.76 & 34.3 & 3.1 \\
\hline MAR-24-MJB & 80.2371 & 82.1716 & 1133 & 313 & $8.39 \mathrm{E}+05$ & $1.58 \mathrm{E}+04$ & 0.96 & 0.99 & 0.32 & 17.23 & 48.3 & 4.3 \\
\hline MAR-26-CJF & 80.2567 & 82.1697 & 879 & 59 & $8.45 \mathrm{E}+04$ & $4.89 \mathrm{E}+03$ & 0.96 & 0.99 & 0.29 & 13.83 & 6.0 & 0.6 \\
\hline \multicolumn{13}{|c|}{ Independence Hills } \\
\hline IND-08-CJF & 80.3466 & 81.6666 & 857 & 3 & $1.72 \mathrm{E}+04$ & $6.86 \mathrm{E}+02$ & 0.96 & 0.99 & 0.26 & 12.27 & 1.3 & 0.1 \\
\hline IND-09-CJF & 80.3466 & 81.6669 & 863 & 3 & $1.55 \mathrm{E}+04$ & $3.65 E+02$ & 0.96 & 0.99 & 0.26 & 12.34 & 1.1 & 0.1 \\
\hline IND-12-CJF & 80.3495 & 81.6676 & 859 & 3 & $3.78 \mathrm{E}+05$ & $3.12 \mathrm{E}+03$ & 0.96 & 0.99 & 0.26 & 12.30 & 27.7 & 2.4 \\
\hline IND-13-CJF & 80.3496 & 81.6671 & 858 & 3 & $3.05 \mathrm{E}+05$ & $1.99 \mathrm{E}+03$ & 0.96 & 0.99 & 0.26 & 12.29 & 22.3 & 2.0 \\
\hline
\end{tabular}


We assume zero surface erosion of the erratics, based on our observations of fresh or unweathered surfaces, and presence of striations and/or ice polish on several of our sub glacially transported erratics. Moreover, based on our analyses of bedrock samples we calculate erosion rates as low as 0.01 to $0.02 \mathrm{~cm} / \mathrm{ka}$ in similar lithologies in the Ellsworth Mountains. These rates are of a similar magnitude to those recorded by cosmogenic studies and field interpretations in other regions of Antarctica including the Dry Valleys area of the Transantarctic Mountains (Ivy-Ochs, 1996). However, these low values contradict some studies based on physical measurements of erosion rates due to wind (up to $2 \mathrm{~cm} / \mathrm{ka}$ ), and weathering due to salt crystallisation (up to $2 \mathrm{~cm} / \mathrm{ka}$ ) in other regions of Antarctica (Gore and Colhoun, 1995; Malin, 1985; Spate et al., 1995). This disparity could be due to these records representing extremely localised effects, such as katabatic winds flowing off the polar plateau (Ivy-Ochs, 1996). Taken together these data suggest that areas of high erosion are localised, with the continental portions of Antarctica such as the Ellsworth Mountains being modified at extremely slow rates. Correction of our dates for these low rates of erosion would lead to $<2 \%$ increase in our calculated exposure ages and does not materially affect our conclusions in the Ellsworth Mountains.

\section{Interpretation}

In order to compare different sites and convert the calculated surface exposure ages into a trajectory of ice sheet thinning since the Last Glacial Maximum it is necessary to normalise the data relative to the modern ice sheet surface. At each site we have measured a 'regional' ice sheet surface so as to remove the effect of local variations in ice topography of a few tens of metres (wind scoops, ablation hollows and local flow variations), where the steep mountain flanks and ice sheet meet.

\section{Ice Sheet Modelling}

The ice sheet model applied in this paper is a modified version of the Glimmer thermomechanical ice sheet model (Rutt et al., 2009). A modification was made to the method of calculating the sliding velocity $\left(\boldsymbol{u}_{B}\right)$, incorporating two different sliding relations, 
depending on whether the ice is grounded above or below sea level as a proxy for hard bed (following (Weertman, 1964)) or soft bed sliding (e.g. (Budd et al., 1984; Huybrechts, 2002)). The hard-bed sliding relation considers the sliding velocity $\left(\boldsymbol{u}_{B}\right)$ to be a linear function of the basal shear stress (considered equivalent to the gravitational driving stress),

$$
\begin{aligned}
& \boldsymbol{u}_{B}=-B_{\mathrm{t}} \rho_{\mathrm{i}} \mathrm{g} H \nabla s \text { if } T_{B}=T_{p m p} \\
& \boldsymbol{u}_{B}=0 \quad \text { if } T_{B}<T_{p m p}
\end{aligned}
$$

where $B_{\mathrm{t}}$ is the traction parameter, $\rho_{\mathrm{i}}$ is ice density, $\mathrm{g}$ is acceleration due to gravity, $H$ is ice thickness, $s$ ice the surface elevation, $T_{\mathrm{B}}$ is the basal ice temperature and $T_{\mathrm{pmp}}$ is the pressure melting temperature.

The soft-bed sliding relation incorporates the inverse of ice thickness above buoyancy $\left(H^{*}\right)$ as a proxy for the effective pressure,

$\boldsymbol{u}_{B}=\frac{-B_{\mathrm{t}} \rho_{\mathrm{i}} \mathrm{g} H \nabla s}{H^{*}}$ if $T_{B}=T_{p m p}$

$\boldsymbol{u}_{B}=0 \quad$ if $T_{B}<T_{p m p}$

where $H^{*}$ is given by,

$H^{*}=H+\frac{\rho_{\mathrm{w}}}{\rho_{\mathrm{i}}} h$,

where $\rho_{\mathrm{w}}$ is the density of sea water and $h$ is the bedrock elevation. Using these relationships the model successfully reproduces the present-day ice sheet (Fig. DR4).

\section{Input datasets}

A modified version of the BEDMAP bed elevation dataset (Le Brocq et al., 2008; Lythe et al., 2001) is employed in this work. The model is forced by surface accumulation (Arthern 
et al., 2006), and average annual mean surface temperatures measured between 1982-2004 (Kwok and Comiso, 2002).

\section{Grounding line migration}

The model does not reproduce ice shelf flow: all ice which exits the (prescribed) grounded ice domain is removed. The grounding line location is held constant by fixing the ice thickness in ice/ocean boundary cells (outside the grounded ice domain) at flotation. The present day grounding line location is given by the ADD (Antarctic Digital Database, http://www.add.scar.org) v5 coastline. A suite of LGM grounding lines was produced by allowing the grounding line location to vary in the two major troughs which exist in the Weddell Sea Embayment. It is in these troughs that the fast flow features (with a low ice thickness and surface profile) are likely to exist, and hence it is here that the major grounding line change will occur. An enclosure-based algorithm was devised to 'advance' the grounding line from the present day configuration in the two troughs. The equilibrium ice sheet resulting from each grounding line position was then compared with the field evidence (Fig 2, Fig DR5). We then selected the maximum and minimum model runs from the range of runs where the ice height differences were consistent with the field constraints. Because we were interested in investigating maximum ice volumes in the Weddell Sea we have used the (higher) trimline from the Patriot Hills as the constraining limit.

\section{Isostasy}

Isostatic adjustment is included, using a simple elastic lithosphere model and a relaxing asthenosphere model (with a relaxation time, $\tau$ ), following (Lambeck and Nakiboglu, 1980) and (Hagdorn, 2003).

\section{Conversion of ice volume to sea level equivalent}

The sea level equivalent was calculated by subtracting the present day, total ice thickness above buoyancy from the LGM total ice thickness above buoyancy (with respect to LGM sea level $(-120 \mathrm{~m})$ and depressed bed elevation). This was then converted into sea level equivalent using ice density of $917 \mathrm{~kg} \mathrm{~m}^{-3}$ and a (fresh) water density of $1000 \mathrm{~kg} \mathrm{~m}^{-3}$, and 
an assumed global ocean surface area of $3.64 \times 10^{14} \mathrm{~m}^{2}$ (Philippon et al., 2006). This yields ice volume estimates of 1.4 to $2.0 \mathrm{~m}$ SLE. In the maximum run some of the excess ice in the WSE is compensated for by thinner ice above $2000 \mathrm{~m}$ altitude. If we only consider ice below $2000 \mathrm{~m}$ then the excess ice volume for the maximum run is $2.85 \mathrm{~m}$. It could be argued that the former ice sheet profile at higher elevations is poorly constrained at the LGM and so a conservative estimate of ice volume could be as high as $2.9 \mathrm{~m}$, but this does not affect our conclusions about mwp-1A.

\section{FIGURES}

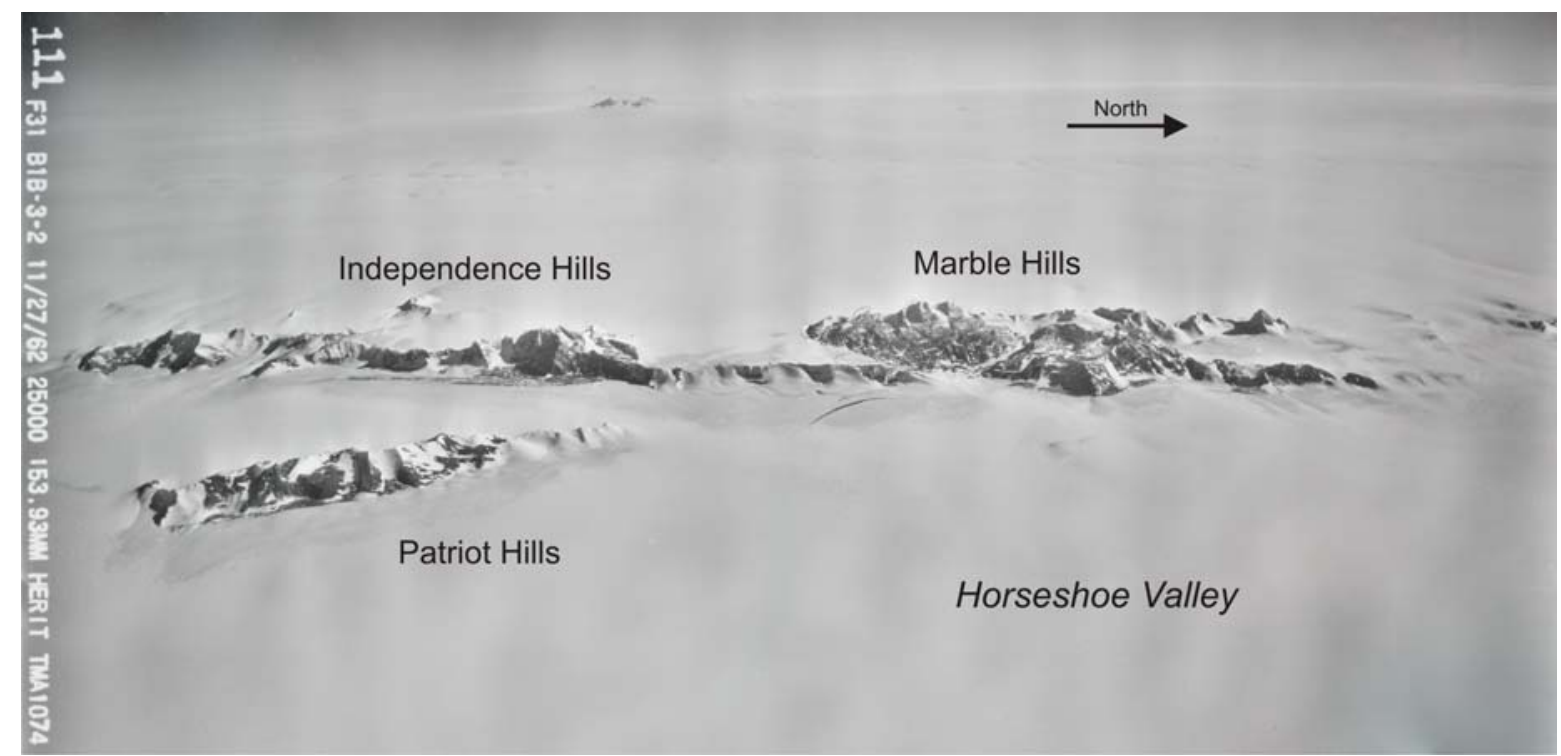

Figure DR1. Oblique photograph showing the location and relationship of sample sites in the southern Heritage Range. Merged panorama is composed of US Navy trimetrogon photographs, nos: TMA-1074-111-F31, TMA-1074-112-F31, TMA-1074-113-F31. Date: 27th November 1962. 
Figure DR2. Locations of erratics sampled for cosmogenic isotope analysis. Sample locations are shown as red dots. (a) Oblique aerial photograph of the southern Heritage Range, including the Patriot Hills and Independence Hills (USGS photograph TMA 899-90 (F33)). (b) Oblique aerial photograph of the Patriot Hills (USGS photograph TMA 1075260 (F31)). (c) Photograph of east side of the Patriot Hills. The limit of fresh drift is located $\sim 230-250 \mathrm{~m}$ above the ice surface but varies between spurs and embayments. (d) Photograph of the east side of the Independence Hills. (e) Photograph of the southern Marble Hills, (f) Photograph of the central Marble Hills. (g) Photograph of the northern Marble Hills. 
ID

CF-01-08

CF-02-08

CF-03-08

CF-08-08

CF-09-08

CF-13-08

CF-14-08

CF-17-08

CF-19-08

CF-21-08

CF-24-08

CF-25-08

CF-28-08

CF-29-08

CF-31-08
10Be Exposure age

$13.4 \pm 1.4 \mathrm{ka}$

$0.7 \pm 0.1 \mathrm{ka}$

$0.5 \pm 0.1 \mathrm{ka}$

$400.8 \pm 38.9 \mathrm{ka}$

$414.7 \pm 40.5 \mathrm{ka}$

$71.6 \pm 6.4 \mathrm{ka}$

$33.3 \pm 3.1 \mathrm{ka}$

$46.0 \pm 4.2 \mathrm{ka}$

$3.9 \pm 0.4 \mathrm{ka}$

$3.0 \pm 0.3 \mathrm{ka}$

$45.1 \pm 4.1 \mathrm{ka}$

$52.6 \pm 4.8 \mathrm{ka}$

$30.0 \pm 2.7 \mathrm{ka}$

$13.7 \pm 1.2 \mathrm{ka}$
$21.3 \pm 1.9 \mathrm{ka}$

\section{ID}

400.2 $\pm 39.2 \mathrm{ka}$

PAT-10-CJF $\quad 446.0 \pm 44.4 \mathrm{ka}$

PAT-13-CJF $387.1 \pm 38.0 \mathrm{ka}$

PAT-14-CJF $\quad 77.2 \pm 7.0 \mathrm{ka}$

PAT-15-CJF $\quad 74.4 \pm 6.7 \mathrm{ka}$

PAT-16-CJF $\quad 50.9 \pm 4.7 \mathrm{ka}$

PAT-18-CJF $33.0 \pm 3.0 \mathrm{ka}$

PAT-20-CJF $\quad 80.4 \pm 7.2 \mathrm{ka}$

PAT-21-CJF $33.2 \pm 3.0 \mathrm{ka}$

PAT-24-CJF $31.3 \pm 2.8 \mathrm{ka}$

PAT-25-CJF $36.8 \pm 3.3 \mathrm{ka}$

PAT-26-CJF $\quad 44.4 \pm 4.0 \mathrm{ka}$

PAT-04-CJF to PAT-26-CJF; CF-01-08 to CF-31-08

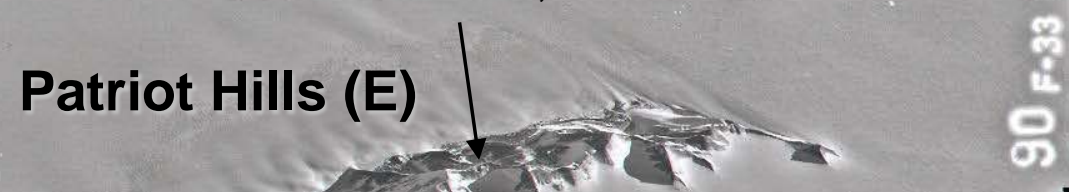

10Be Exposure age

$8.2 \pm 0.8 \mathrm{ka}$

$5.7 \pm 1.8 \mathrm{ka}$

$9.0 \pm 1.0 \mathrm{ka}$

$6.6 \pm 1.0 \mathrm{ka}$

6.

PAT-05-MJB $=$ PAT-01-MJB

YPAT-03-MJB Patriot Hills (W) PAT-04-MJB

Fig S2 (a)

\section{Marble Hills}

PAT-04-MJB

PAT-05-MJB

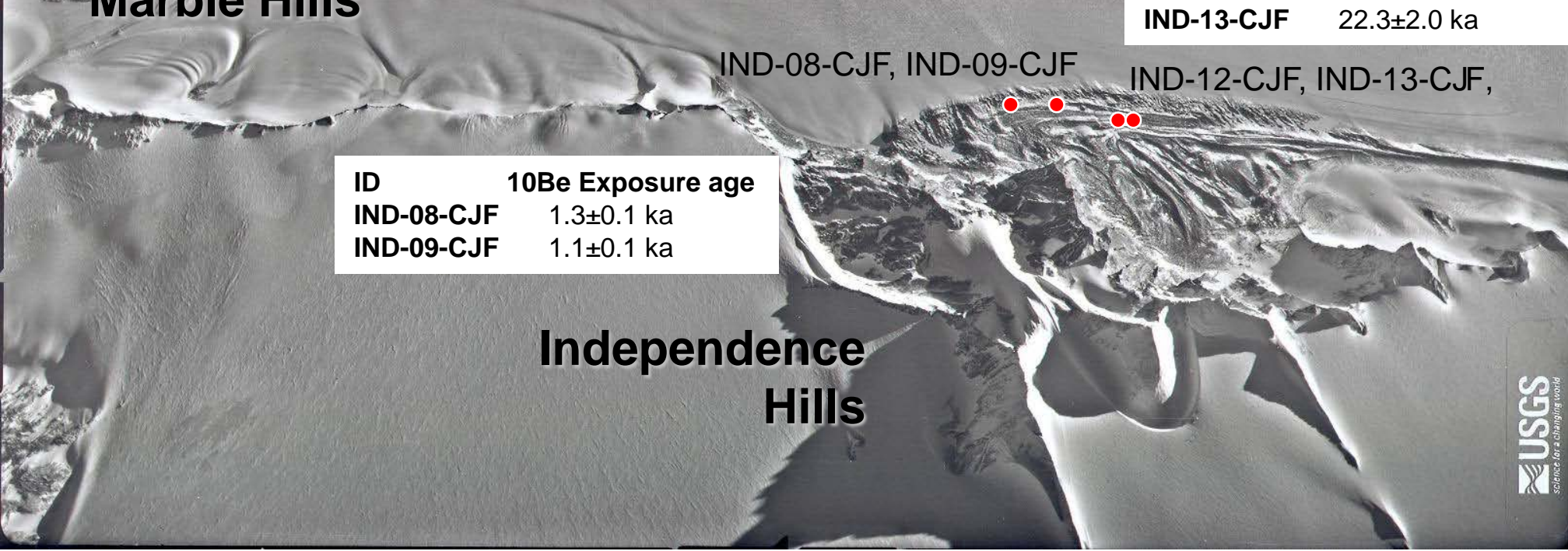




\section{ID 10Be Exposure age}

PAT-04-CJF 29.8 $\pm 2.7 \mathrm{ka}$

PAT-14-CJF $\quad 77.2 \pm 7.0 \mathrm{ka}$

PAT-15-CJF $\quad 74.4 \pm 6.7 \mathrm{ka}$

PAT-16-CJF $\quad 50.9 \pm 4.7 \mathrm{ka}$

CF-13-08 $\quad 71.6 \pm 6.4 \mathrm{ka}$

CF-14-08 33.3 $\pm 3.1 \mathrm{ka}$

ID

CF-17-08

CF-19-08

CF-21-08

CF-24-08
10Be Exposure age

$46.0 \pm 4.2 \mathrm{ka}$

$21.3 \pm 1.9 \mathrm{ka}$

$3.9 \pm 0.4 \mathrm{ka}$

$3.0 \pm 0.3 \mathrm{ka}$
ID 10Be Exposure age

PAT-08-CJF $\quad 400.2 \pm 39.2 \mathrm{ka}$

PAT-10-CJF $\quad 446.0 \pm 44.4 \mathrm{ka}$

CF-08-08 400.8 $\pm 38.9 \mathrm{ka}$

CF-09-08 414.7 $\pm 40.5 \mathrm{ka}$

PAT-13-CJF $387.1 \pm 38.0 \mathrm{ka}$

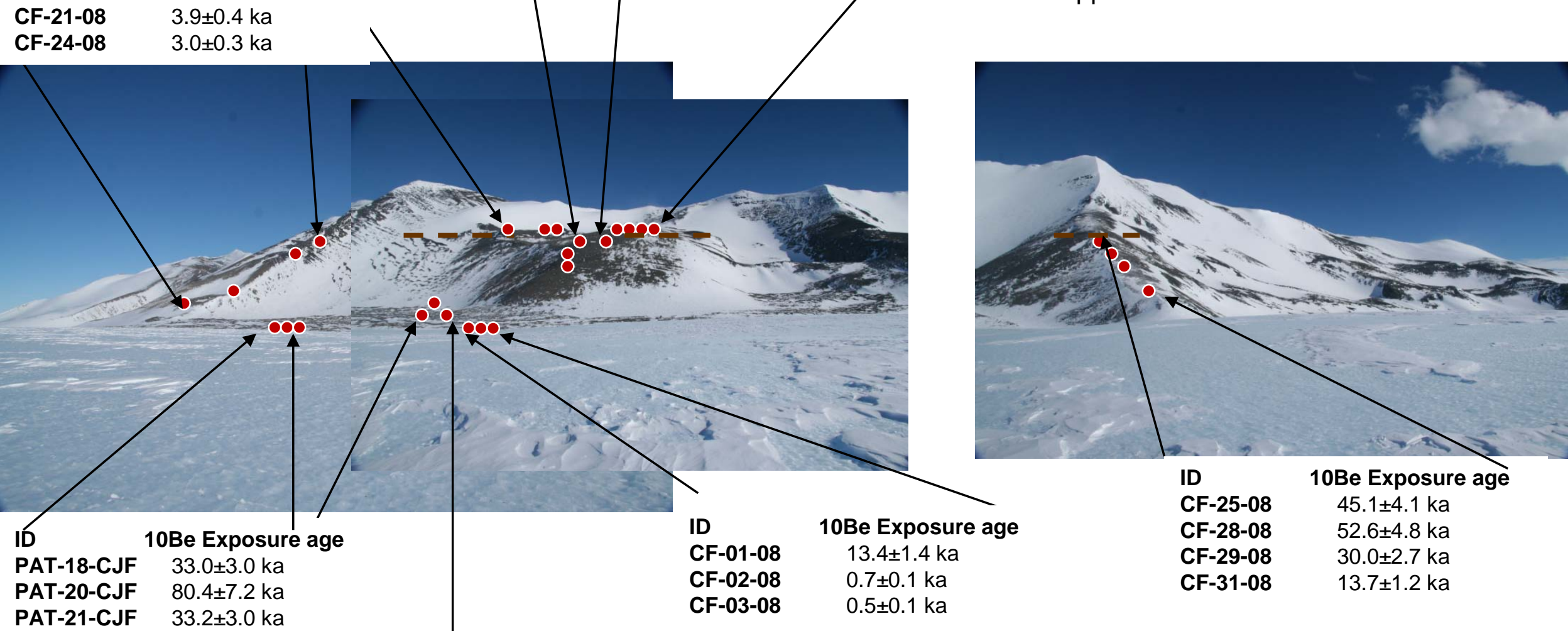

\section{I}

10Be Exposure age

PAT-24-CJF $31.3 \pm 2.8 \mathrm{ka}$

PAT-25-CJF $36.8 \pm 3.3 \mathrm{ka}$

PAT-26-CJF $\quad 44.4 \pm 4.0 \mathrm{ka}$

- - - Upper limit of fresh clasts

ID

CF-28-08

CF-29-08

$0.7 \pm 0.1 \mathrm{ka}$

$0.5 \pm 0.1 \mathrm{ka}$

Fig S2 (c) 


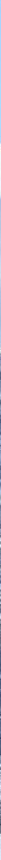

ID

10Be Exposure age

IND-08-CJF $1.3 \pm 0.1 \mathrm{ka}$

IND-09-CJF 1.1 $0.1 \mathrm{ka}$

Fig S2 (d) 


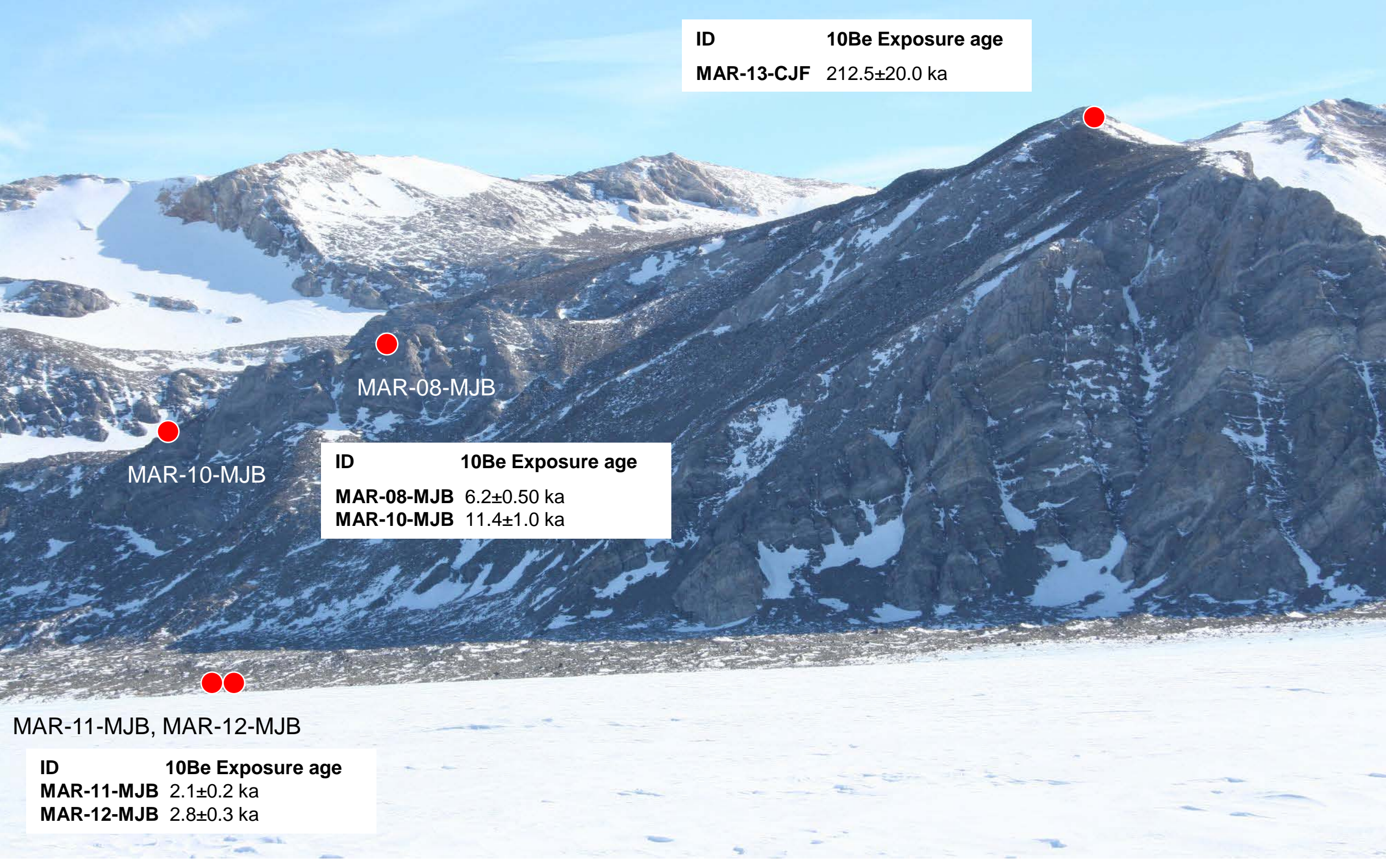

Fig S2 (e) 


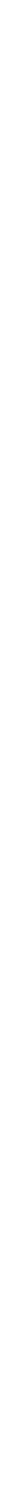

Fig S2 (g) 


\section{Figure S3a}

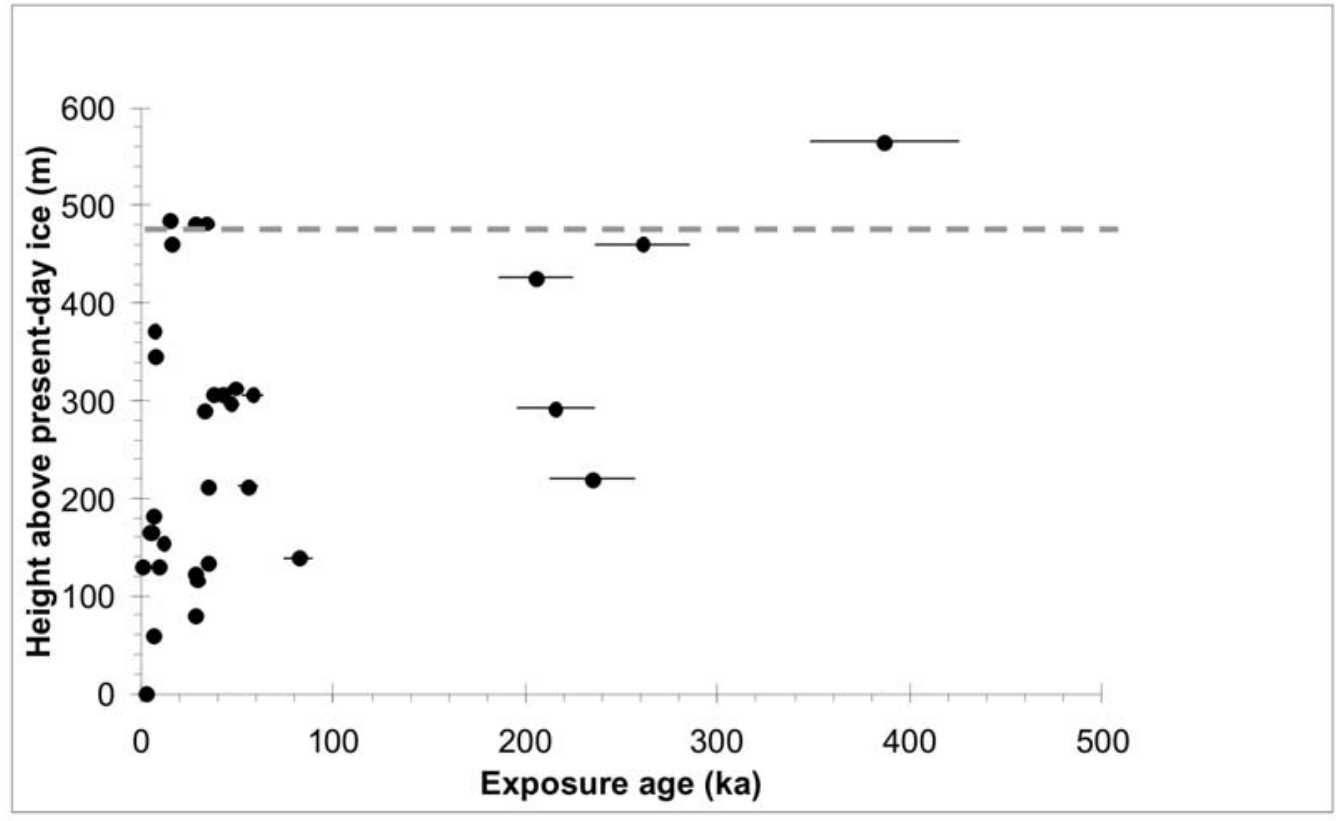

\section{Figure S3b}

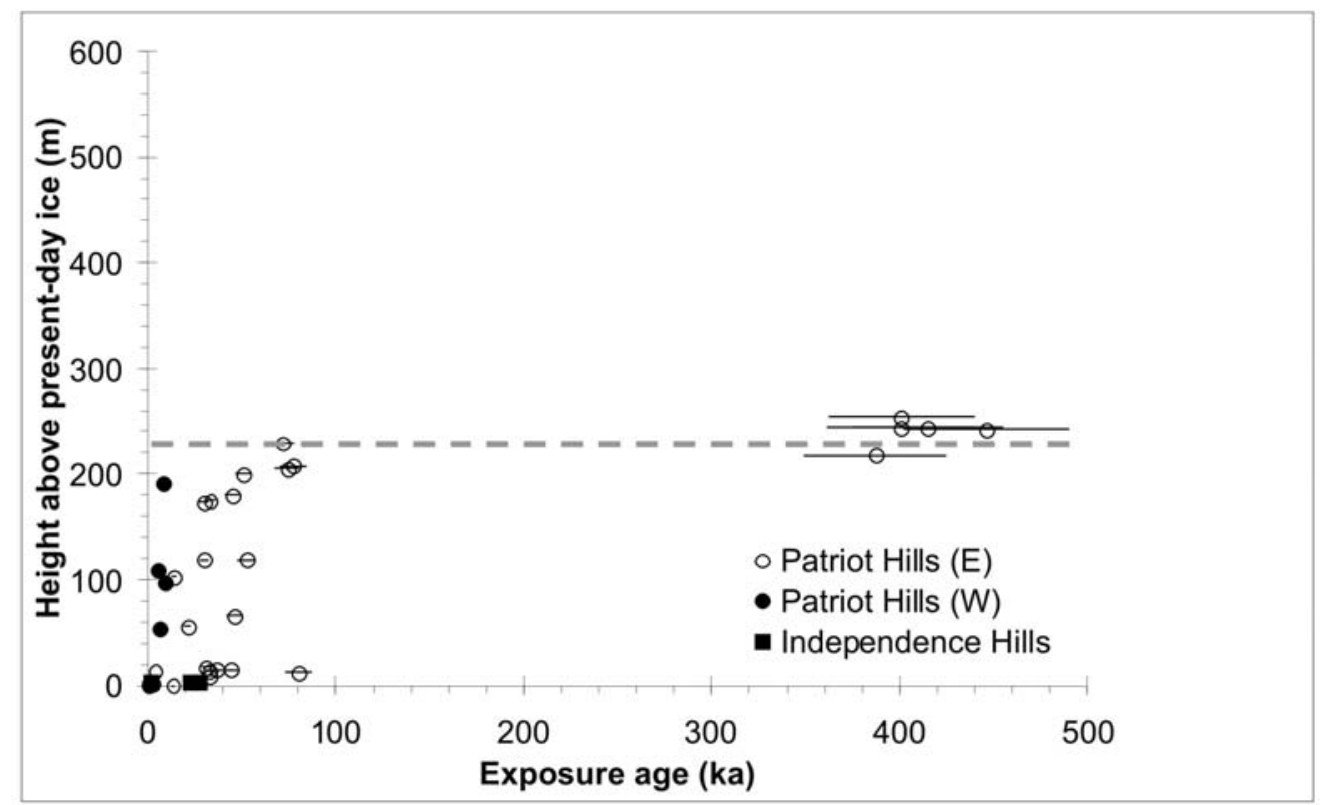

Figure DR3. Plot of exposure ages against height above present-day ice of the West Antarctic Ice Sheet in the southern Ellsworth Mountains. (a) Marble Hills (all samples), (b) Patriot and Independence Hills (all samples). See Fig 2 for detail plots of samples $<50 \mathrm{ka}$ that show the post-LGM thinning history. 


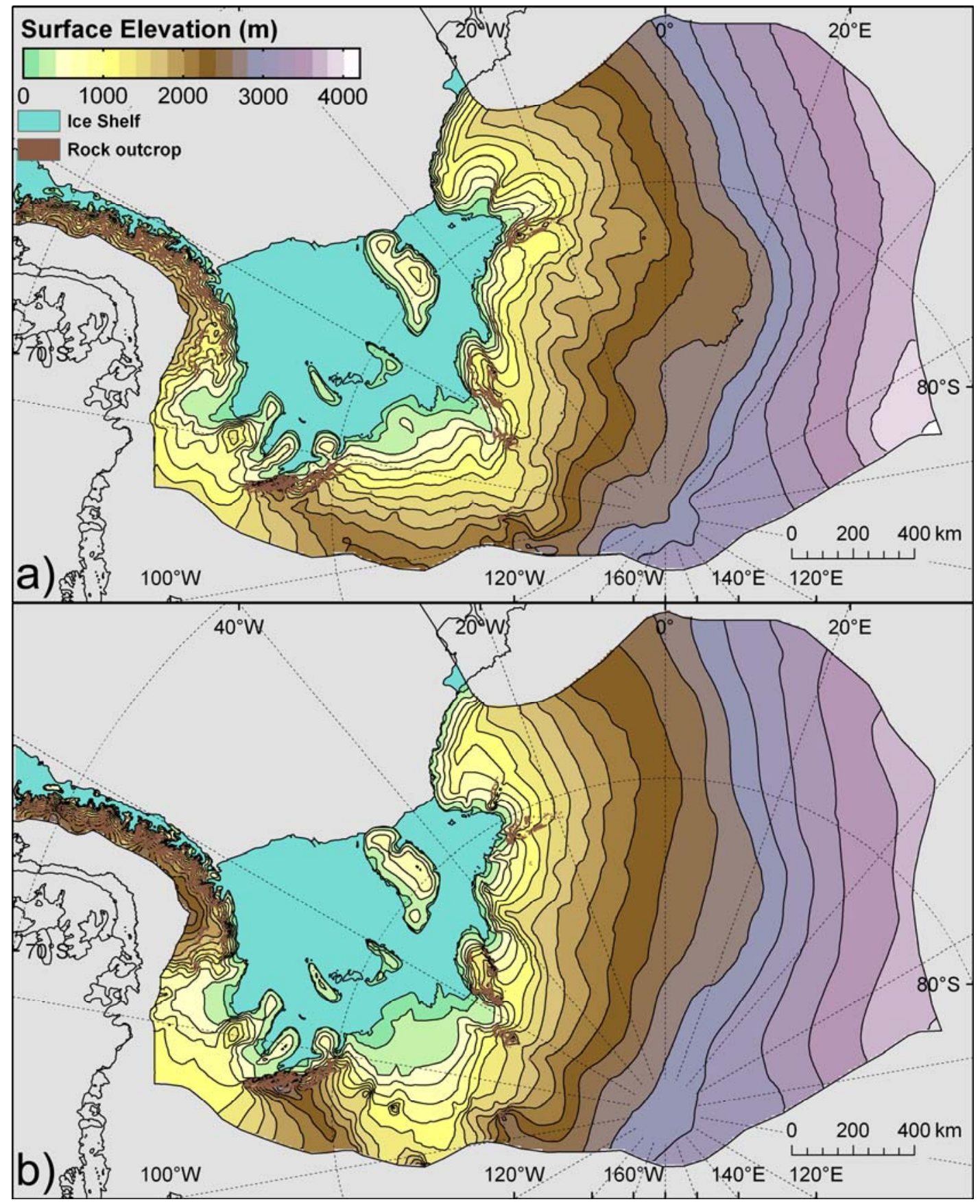

Figure DR4. Modelled reconstruction of the ice sheet in the Weddell Sea embayment (a) Modelled present-day, (b) Measured present-day. 


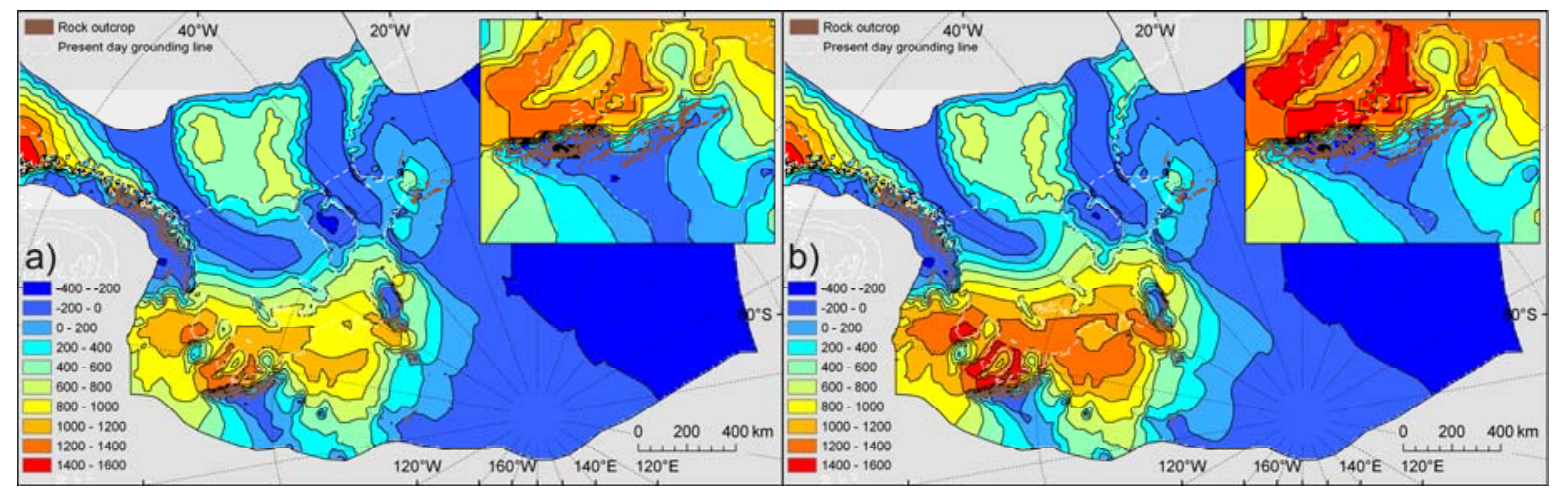

Figure DR5. Ice height differences (modelled LGM - modelled present) for the Weddell Sea sector and Ellsworth Mountains (insets) (a) Minimum LGM run (see Fig 3a), (b) Maximum LGM run (see Fig 3b).

\section{References}

Arthern, R.J., Winebrenner, D.P., and Vaughan, D.G., 2006, Antarctic snow accumulation mapped using polarization of 4.3-cm wavelength microwave emission: Journal of Geophysical Research-Atmospheres, v. 111.

Balco, G., John, S., Lifton, N., and Dunai, T., 2008, A simple, internally consistent, and easily accessible means of calculating surface exposure ages and erosion rates from Be-10 and Al-26 measurements: Quaternary Geochronology, v. 3, p. 174-195.

Budd, W.F., Jenssen, D., and Smith, I.N., 1984, A 3-Dimensional Time-Dependent Model of the West Antarctic Ice-Sheet: Annals of Glaciology, v. 5, p. 29-36.

Freeman, S., Xu, S., Schnabel, C., Dougans, A., Tait, A., Kitchen, R., Klody, G., Loger, R., Pollock, T., Schroeder, J., and Sundquist, M., 2004, Initial measurements with the SUERC accelerator mass spectrometer: Nuclear Instruments \& Methods in Physics

Research Section B-Beam Interactions with Materials and Atoms, v. 223-24, p. 195198.

Gore, D.A., and Colhoun, E., 1995, Regional contrasts in terrain and glacial sediments, Vestfold Hills, East Antarctica, VII International Symposium on Antarctic Earth Sciences: Siena, Italy, p. 163. 
Gosse, J.C., and Phillips, F.M., 2001, Terrestrial in situ cosmogenic nuclides: theory and application: Quaternary Science Reviews, v. 20, p. 1475-1560.

Hagdorn, M.K.M., 2003, Reconstruction of the Past and Forecast of the Future European and British Ice Sheets and Associated Sea-Level Change: Edinburgh, University of Edinburgh.

Huybrechts, P., 2002, Sea-level changes at the LGM from ice-dynamic reconstructions of the Greenland and Antarctic ice sheets during the glacial cycles: Quaternary Science Reviews, v. 21, p. 203-231.

Ivy-Ochs, S., 1996, The dating of rock surfaces using in situ produced 10Be, 26Al and $36 \mathrm{Cl}$, with examples from Antarctica and the Swiss Alps [Ph.D. dissertation no. 11763 thesis]: Zurich, Switzerland, ETH.

Kohl, C.P., and Nishiizumi, K., 1992, Chemical Isolation of Quartz for Measurement of Insitu-Produced Cosmogenic Nuclides: Geochimica Et Cosmochimica Acta, v. 56, p. 3583-3587.

Kwok, R., and Comiso, J.C., 2002, Spatial patterns of variability in Antarctic surface temperature: Connections to the Southern Hemisphere Annular Mode and the Southern Oscillation: Geophysical Research Letters, v. 29, p. doi;10.1029/2002GL015415.

Lal, D., 1991, Cosmic ray labeling of erosion surfaces: in situ nuclide production rates and erosion models: Earth and Planetary Science Letters, v. 104, p. 424-439.

Lambeck, K., and Nakiboglu, S.M., 1980, Seamount loading and stress in the ocean lithosphere: Journal of Geophysical Research, v. 85, p. 6403-6418.

Le Brocq, A.M., Hubbard, A., Bentley, M.J., and Bamber, J.L., 2008, Subglacial topography inferred from ice surface terrain analysis reveals a large un-surveyed basin below sea level in East Antarctica: Geophysical Research Letters, v. 35, p. doi:10.1029/2008GL034728.

Lythe, M.B., Vaughan, D.G., and BEDMAP consortium, 2001, BEDMAP: A new ice thickness and subglacial topographic model of Antarctica: Journal of Geophysical Research-Solid Earth, v. 106, p. 11335-11351. 
Mackintosh, A., White, D., Fink, D., Gore, D.B., Pickard, J., and Fanning, P.C., 2007, Exposure ages from mountain dipsticks in Mac. Robertson Land, East Antarctica, indicate little change in ice-sheet thickness since the Last Glacial Maximum: Geology, v. 35, p. 551-554.

Malin, M.C., 1985, Abrasion rate observations in Victoria Valley, Antarctica: 340-day experiment: Antarctic Journal of the United States, v. 19, p. 14-16.

Nishiizumi, K., 2002, 10Be, 26Al, 36Cl and 41Ca standards: Abstracts of the Ninth International Conference on Accelerator Mass Spectrometry (AMS-9), Nagoya, Japan.

Nishiizumi, K., Imamura, M., Caffee, M.W., Southon, J.R., Finkel, R.C., and McAninch, J., 2007, Absolute calibration of Be-10 AMS standards: Nuclear Instruments \& Methods in Physics Research Section B-Beam Interactions with Materials and Atoms, v. 258, p. 403-413.

Philippon, G., Ramstein, G., Charbit, S., Kageyama, M., Ritz, C., and Dumas, C., 2006, Evolution of the Antarctic ice sheet throughout the last deglaciation: A study with a new coupled climate - north and south hemisphere ice sheet model: Earth and Planetary Science Letters, v. 248, p. 750-758.

Rutt, I.C., Hagdorn, M., Hulton, N.R.J., and A., P., 2009, The 'Glimmer' community ice sheet model: Journal of Geophysical Research, v. 114, F02004.

Spate, A.P., Burgess, J.S., and Shevlin, J., 1995, Rates of rock surface lowering, Princess Elizabeth Land, eastern Antarctica: Earth Surface Processes and Landforms, v. 20, p. 567-573.

Stone, J.O., 2000, Air pressure and cosmogenic isotope production: Journal of Geophysical Research-Solid Earth, v. 105, p. 23753-23759.

Stone, J.O., Balco, G.A., Sugden, D.E., Caffee, M.W., Sass, L.C., Cowdery, S.G., and Siddoway, C., 2003, Holocene deglaciation of Marie Byrd Land, West Antarctica: Science, v. 299, p. 99-102.

Weertman, J., 1964, The theory of glacier sliding: Journal of Glaciology, v. 5, p. 287-303. 